\title{
A PRESENÇA DO ENSINO RELIGIOSO NA LEGISLAÇÃO EDUCACIONAL DO GRÃO-PARÁ (1841 - 1887)
}

\author{
Viviane Dourado \\ Universidade Federal do Pará \\ vivianedrd2@gmail.com \\ Alberto Damasceno \\ Universidade Federal do Pará \\ albertod@ufpa.br \\ Karla Almeida \\ Universidade Federal do Pará \\ kalmeidaufpa@gmail.com \\ Suellem Pantoja \\ Universidade Federal do Pará \\ smartinspantoja@gmail.com
}

\begin{abstract}
RESUMO
Este artigo resulta de uma pesquisa mais ampla sobre a História da Educação no Pará, tem como objetivo discutir preliminarmente a presença do ensino religioso na legislação educacional da Província do Pará, entre os anos de 1841 e 1887, para desta forma compreender sua trajetória no período monárquico. Para sua elaboração realizamos uma pesquisa histórica e fizemos uma análise documental, tendo como fontes primárias nove normativas educacionais do período. Utilizamos como referencial teórico pesquisas de Castro e Baldino (2015), Costa e França (2105), Damasceno (2017), Faria Filho (2000), Muniz e Gonçalvez (2015), Oliveira (2004) e Souza (1998). A partir disso, foi possível compreender a importância e a influência do ensino religioso, especificamente da igreja católica junto à Coroa, realidade que se manteve até o advento da República em 1889.
\end{abstract}

Palavras-chave: Ensino religioso. Legislação educacional. Pará.

\section{LA PRESENCIA DE LA ENSEÑANZA RELIGIOSA EN LA LEGISLACIÓN EDUCATIVA DEL GRAN PARÁ (1841-1887)}

\section{RESUMEN}

Este artículo es el resultado de una investigación más amplia sobre la Historia de la Educación en Pará. Su objetivo es discutir la presencia de la enseñanza religiosa en la legislación educativa de la Provincia de Pará, entre 1841 y 1887, para comprender su trayectoria en el período. monárquico Para su elaboración realizamos una investigación histórica e hicimos un análisis documental, teniendo como fuentes primarias nueve normas educativas de la época. Utilizamos como referencia de investigación teórica Castro y Baldino (2015), Costa y França (2105), Damasceno (2017), Faria Filho (2000), Muniz y Gonçalvez (2015), Oliveira (2004) y Souza (1998). A partir de esto, fue posible comprender la importancia y la influencia de la enseñanza religiosa, específicamente la 


\title{
$(\mathrm{cc})$ EY
}

iglesia católica con la Corona, una realidad que permaneció hasta el advenimiento de la República en 1889.

Palabras clave: Educación religiosa. Legislación educativa. Pará.

\section{THE PRESENCE OF RELIGIOUS TEACHING IN THE EDUCATIONAL LEGISLATION OF GRAND PARÁ (1841 - 1887)}

\begin{abstract}
This article results from a broader research on the History of Education in Pará. Its objective is to discuss the presence of religious teaching in the educational legislation of the Province of Pará, between 1841 and 1887, in order to understand its trajectory in the period. monarchic. For its elaboration we carried out a historical research and made a documentary analysis, having as primary sources nine educational norms of the period. We used as a theoretical reference research from Castro and Baldino (2015), Costa and França (2105), Damasceno (2017), Faria Filho (2000), Muniz and Gonçalvez (2015), Oliveira (2004) and Souza (1998). From this, it was possible to understand the importance and influence of religious teaching, specifically the Catholic church with the Crown, a reality that remained until the advent of the Republic in 1889.
\end{abstract}

Keywords: Religious education. Educational legislation. Pará.

\section{LA PRESENCE DE L'ENSEIGNEMENT RELIGIEUX DANS LA LEGISLATION EDUCATIVE DU GRAND PARA (1841 - 1887) \\ RÉSUMÉ}

Cet article résulte d'une recherche plus large sur l'histoire de l'éducation au Pará. Son objectif est de discuter de la présence de l'enseignement religieux dans la législation éducative de la province du Pará, entre 1841 et 1887, afin de comprendre sa trajectoire dans la période. monarchique. Pour son élaboration nous avons effectué une recherche historique et effectué une analyse documentaire, ayant comme sources primaires neuf normes éducatives de l'époque. Nous avons utilisé comme recherche de référence théorique de Castro et Baldino (2015), Costa et França (2105), Damasceno (2017), Faria Filho (2000), Muniz et Gonçalvez (2015), Oliveira (2004) et Souza (1998). À partir de cela, il a été possible de comprendre l'importance et l'influence de l'enseignement religieux, en particulier la église catholique avec la Couronne, une réalité qui est restée jusqu'à l'avènement de la République en 1889.

Mots clés: Enseignement religieux. Législation éducative. Pará.

\section{INTRODUÇÃO}

$\mathrm{O}$ ensino religioso enquanto disciplina presente nas normativas educacionais acabou despertando nosso interesse para investigarmos seus conteúdos dispostos em normas educacionais 


\section{(cc) $\mathbf{E Y}$}

paraenses durante o Império, mais especificamente após o Ato Adicional Diogo de Feijó de 1834. Para seu desenvolvimento fizemos a coleta de material na Biblioteca Estadual e no Arquivo Público do Estado para, posteriormente, iniciarmos a análise de nove documentos oficiais que demarcaram o recorte temporal do trabalho de 1841 a 1887. Nosso objetivo é discutir preliminarmente a presença do ensino religioso na legislação educacional da Província do Pará, entre os anos de 1841 e 1887, tendo em vista compreender sua trajetória no período monárquico.

Realizamos a revisão da literatura a partir de um levantamento bibliográfico que relacionou contribuições de diferentes autores, fazendo uso da pesquisa histórica que compreendemos como um "tipo de pesquisa científica, cuja especificidade consiste, do ponto de vista teórico-metodológico, na abordagem histórica - no tempo - do fenômeno educativo em suas diferentes facetas" (MORTATTI, 1999, p. 73). Nesta pesquisa, nos deparamos com informações que não podiam ser mensuradas e que mereciam uma atenção mais sensível e profunda para além das quantidades envolvidas.

Levamos a efeito, também, uma pesquisa documental cujo objetivo foi o de extrair o máximo de informações explícitas e implícitas das fontes investigadas.

Para analisarmos essas fontes utilizamos a técnica da análise documental com vistas a "extrair os elementos informativos [...] a fim de expressar seu conteúdo de forma abreviada, resultando na conversão de um documento primário em documento secundário" (KRIPKA; SCHELLER; BONOTTO, 2015, p. 61), buscando produzir inferências possíveis a partir do texto produzido pelas autoridades da época.

Como primeira etapa para a análise documental, realizamos um exame inicial dos documentos que foram analisados através de uma "leitura flutuante" que consiste em "realizar uma leitura superficial dos documentos a fim de escolhê-los" (BARDIN, 1979 apud KRIPKA; SCHELLER; BONOTTO, 2015, p. 65), ou seja, uma primeira aproximação com os documentos a serem analisados, escolhidos e interpretados para confirmar o foco do estudo. Em seguida, realizamos a exploração dessas fontes primárias, lendo "atentamente toda a documentação a fim de codificar, classificar e categorizar as informações contidas” (BARDIN, 1979 apud KRIPKA; SCHELLER; BONOTTO, 2015, p. 67).

A estrutura do artigo está organizada em três partes, além das considerações finais. Na primeira apresentamos o contexto do surgimento do ensino religioso como disciplina escolar inserida no currículo; na segunda apresentamos brevemente a organização da instrução pública na 


\section{$(c)$ EY}

Província do Pará no início do período em estudo e na terceira exploramos as normativas educacionais acerca do ensino religioso na província do Pará. Posteriormente, apresentamos nossas considerações finais acerca das informações expostas.

\section{O CONTEXTO DO SURGIMENTO DO ENSINO RELIGIOSO}

Por meio da Igreja Católica, o Brasil recebeu uma herança cultural ibérica, principalmente a partir da chegada da Ordem dos Jesuítas em 1549 que, de acordo com Oliveira (2004), foi responsável pela catequização indígena e pela educação da elite colonizadora. Foi desta forma, portanto, que os jesuítas criaram um sistema educacional que "fornecia aos elementos das classes dominantes uma educação clássica e humanista como era o ideal europeu da época" (OLIVEIRA, 2004, p. 946).

Entretanto, com a Reforma Protestante em curso nos países da Europa no século XVI os católicos passaram a depositar no continente americano a esperança de se contrapor àquele movimento, arregimentando novas almas para seu rebanho. Naquele período, como informam Castro e Baldino (2015), a Igreja buscava nas novas terras a possibilidade de sua expansão religiosa devido à perda de adeptos devido à reforma protestante.

Desta forma, esses religiosos chegaram em terras brasileiras junto com os primeiros colonizadores, primeiramente os franciscanos para, em seguida, chegarem os jesuítas, que "vinham com a missão de transmitir 'aos pagãos' a verdadeira e única mensagem capaz de salvar a alma e dar dignidade ao corpo" (CASTRO; BALDINO, 2015, p. 69) com a intenção de catequizar os nativos em um "contexto da colonização do país, enquanto ensino da doutrina cristã católica, catequese e ensino da religião" (MUNIZ; GOLÇALVES, 2015, p. 05).

Sendo hegemônica na colônia, a educação jesuítica reproduziu o espírito da Idade Média com o "aprisionamento do homem ao dogma da tradição escolástica, a sua submissão à autoridade e à rígida ordenação social, avesso ao livre exame e à experimentação" (OLIVEIRA, 2004, p. 946). Apesar disso, é importante ressaltar que a educação jesuítica proporcionou:

resultados significativos, tais como: "a transmissão de uma educação homogênea - mesma língua, mesma religião, mesma visão de mundo, mesmo ideal de 'homem culto', ou seja, letrado e erudito — plasmando, de norte a sul, uma identidade cultural; a catequese como processo de aculturação, embora destrutiva, de filhos de colonos e órfãos, trazidos de Portugal, com meninos índios e mestiços, elidindo a distinção de raças e dissolvendo costumes não europeus; a

Rev. Iberoam. Patrim. Histórico-Educativo, Campinas (SP), v. 6, p. 1-19, e020013, 2020. 


\section{$(c)$ EY}

contraposição da escola e da Igreja à autoridade patriarcal da casa-grande (ALBUQUERQUE, 1993, p. 18 apud OLIVEIRA, 2004, p. 946).

Esse projeto educacional se manteve por meio de doações de usuários, além dos recursos coletados por meio do "subsídio literário, imposto por alvará régio e com vigência até o início do século XIX” (OLIVEIRA, 2004, p. 947). Com a chegada da família real e da corte em 1808 a paisagem cultural do Brasil passou a apresentar mudanças importantes. O país passou a viver em um ambiente de expansão cultural onde se destacavam a criação do Museu Real, do Jardim Botânico, da Biblioteca Pública e a Imprensa Régia. No setor educacional, surgiam os primeiros cursos superiores, organizados "em aulas avulsas e com um sentido profissional prático" (OLIVEIRA, 2004, p. 947).

No âmbito das ideias provenientes do Iluminismo e de outras correntes de pensamento filosófico que se propagavam na Europa (CASTRO; BALDINO, 2015) e, em decorrência disso, a Igreja ia perdendo aos poucos sua hegemonia tanto na Europa quanto na Colônia até a expulsão dos jesuítas do Brasil em 1759 pelo Marquês de Pombal ${ }^{1}$.

Segundo Castro e Baldino (2015) o Marquês foi uma figura representativa nos conflitos entre a Igreja e a Coroa Portuguesa. Após a expulsão dos jesuítas as reformas realizadas por ele, enquanto primeiro-ministro de Portugal, extinguiram “o único 'sistema' de educação do ViceReinado do Brasil” (OLIVEIRA, 2004, p. 946).

Naquele momento a educação era um dos pontos centrais a ser corrigido já que se encontrava monopolizada pelos jesuítas, cujo ensino "se mantinha preso a Aristóteles e avesso aos métodos modernos de fazer ciência" (CASTRO; BALDINO 2015, p. 70). Além disso, a reforma educacional do Marquês de Pombal instituiu:

as aulas régias, que eram aulas ministradas por professores que, por si, organizavam seus locais de trabalho - casas, salas - onde se lecionava aulas de latim, grego, filosofia e retórica. Após montarem essas "escolas", esses professores solicitavam da Coroa o pagamento pelo seu trabalho. (CASTRO; BALDINO, 2015, p. 70).

A partir de então, o Estado tentou assumir as responsabilidades e os encargos da educação mas essa iniciativa não logrou o devido êxito devido à baixa capacidade dos seus responsáveis, o que fragilizou o desempenho das escolas régias recentemente criadas que se mostraram "incapazes de assimilar toda modernidade que norteava a iniciativa pombalina" (OLIVEIRA, 2004, p. 947). 


\section{$(c c)$ EY}

Apesar da precariedade e das dificuldades, houve modificações educacionais na metrópole e na Colônia, pois começavam as iniciativas de um sistema público de ensino, apesar de o ser para poucos, uma vez que o salário dos professores eram responsabilidade da Coroa (CASTRO; BALDINO, 2015).

Se as reformas pombalinas obtiveram melhor aplicação em Portugal, isso não aconteceu na Colônia pois "a implantação das aulas régias encontrou, de um lado, resistência; principalmente pela falta de recursos financeiros" (CASTRO; BALDINO, 2015, p. 71) devida, sobretudo à baixa capacidade de investimento das províncias. Esse problema se manteve durante muito tempo e causou prejuízos incalculáveis à formação de nosso povo, principalmente dos mais pobres.

Segundo Faria Filho (2000), os estudos acerca da educação brasileira no período imperial, mostram que em várias Províncias havia uma discussão sobre a necessidade de escolarizar a população, principalmente as consideradas "camadas inferiores da sociedade" (FARIA FILHO, 2000).

Em 1834, o Ato Adicional de Diogo de Feijó promoveu uma política de descentralização administrativa, dando às Províncias o direito de legislar sobre a instrução pública e promover a criação de estabelecimentos próprios. Essas mudanças acabaram por implicar em uma dualidade na oferta do ensino ficando ao poder central reservado "o direito de promover e regulamentar a educação no Rio de Janeiro e a educação de nível superior, em todo o Império" (ROMANELLI 1999 apud OLIVEIRA, 2004, p. 948), enquanto às Províncias foi dada a incumbência de regular e ofertar a educação primária e secundária.

$\mathrm{Na}$ sua estrutura, portanto, o poder central se encarregou do ensino superior enquanto os outros níveis ficaram sob responsabilidade das Províncias, com exceção do Colégio Pedro II, que deveria servir de modelo para as outras escolas provinciais (OLIVEIRA, 2004). Porém, a carência de recursos e a falta de interesse das elites com a instrução do povo acabaram impedindo a organização de uma rede adequada e eficiente de escolas, o que resultou no fato de que "o ensino secundário foi assumido, em geral, pela iniciativa particular, especialmente pela Igreja. $\mathrm{O}$ ensino primário, novamente, ficou abandonado" (OLIVEIRA, 2004, p. 948). A educação das maiorias, na prática, foi desprezada e o que restou do período monárquico, além da instrução das elites, se constituiu apenas em "uma série de debates sobre a estruturação de uma educação nacional, com a tentativa da criação de um sistema em que a educação popular era considerada um requisito 


\section{$(c)$ EY}

fundamental — sinônimo de liberdade e riqueza; antônimo de pobreza e despotismo" (OLIVEIRA, 2004, p. 948).

Ainda na década de 30, após a edição do Ato Adicional, em que pese várias leis provinciais estabelecerem a obrigatoriedade de frequência da população livre à escola, ainda assim as dificuldades eram grandes. Segundo Faria Filho (2000) "muitos foram os limites enfrentados por aqueles que defendiam que a educação deveria ser estendida à maioria da população" (FARIA FILHO, 2000, p. 135), neste sentido, é importante considerar que a escola não tinha um lugar social de destaque de forma que era necessário "afirmar a presença do Estado nessa área e também produzir, paulatinamente, a centralidade do papel da instituição escolar na formação das novas gerações" (FARIA FILHO, 2000, p. 135-136).

Sendo assim, os defensores da importância da escola no processo de civilização do povo precisaram, além de produzir o próprio lugar da escola, "apropriar, remodelar, ou recusar tempos, espaços, conhecimentos, sensibilidades e valores próprios de tradicionais instituições de educação" (FARIA FILHO, 2000, p. 136). Tratava-se de uma tarefa bastante complexa pois, para a elite brasileira, a escola para os pobres, mesmo estes sendo brancos e livres "não deveria ultrapassar o aprendizado das primeiras letras" (FARIA FILHO, 2000, p. 136).

A presença do ensino de religião nos documentos legais do Império não pode prescindir de uma premissa importante: a de que seu fundamento era a própria Constituição do Império, outorgada por D. Pedro I em março de 1824. Nesta Carta a religião católica apostólica romana era estabelecida como a religião oficial do Império e, embora outras religiões fossem permitidas, estas o eram apenas em cultos domésticos ou particulares e "sem fórma alguma exterior do Templo" (Art. $5^{\circ}$ ).

Um aspecto importante, que comprova a extraordinária força e influência da Igreja Católica no governo do Império é o fato de que a Constituição determinava que não podiam ser eleitores aqueles que não professassem a Religião do Estado, ou seja, a religião católica (art. 95, inciso III). Para além dessas medidas, a Constituição determinava que o Imperador, antes de ser aclamado, deveria jurar "manter a Religião Catholica Apostolica Romana". Da mesma forma, seu herdeiro - ao completar 14 anos - e os Conselheiros de Estado - antes de tomarem posse deveriam fazer o mesmo juramento.

Neste sentido, e considerando que "o currículo é uma ferramenta de seleção da cultura, de organização do conhecimento, em contexto histórico determinado, uma construção social" 


\section{$(c)$ EY}

(MUNIZ; GOLÇALVES, 2015, p. 03) os conteúdos que deveriam ser ensinados para as crianças confirmavam a supremacia da Igreja Católica e tinham sua inserção assegurada no currículo escolar. Com isso, o ensino religioso ganhou força, atraindo públicos e reforçando sua permanência no rol das matérias indispensáveis à formação do cidadão brasileiro

\section{A TENTATIVA DE ORGANIZAÇÃO DA INSTRUÇÃO PÚBLICA}

Segundo Costa e França (2015) Uma das primeiras medidas de D. Antônio de Macedo Costa foi no campo da educação, começando com a reforma do Seminário Diocesano. Para ele, a reforma dos seminários brasileiros iria ajudar na formação de um clero ilustrado, apto a desenvolver a regeneração moral do país pela prática da religião católica. Nesse sentido, D. Macedo Costa concebeu a educação religiosa e a instrução secular como inseparáveis, mas com a supremacia da primeira. Para ele, só um clero ilustrado seria capaz de manter as "sólidas bases o edifício da moralidade pública" (COSTA; FRANÇA, 2015, p. 56), por isso, a educação religiosa estava à "frente de todas as obras da inteligência e indústria humana, na frase de um moderno economista, semelhante à Arca da Aliança, que marchava diante do povo".

Como tentativa de regulamentar a instrução pública na Província, em junho de 1841 a Assembleia Legislativa Provincial decretou e Bernardo de Souza Franco, o então Vice-Presidente da Província do Grão - Pará, sancionou a Lei nº 97 que regulava a instrução pública primária e secundária da Província, que visava organizar o ensino público que, na época, se encontrava em "estado precário e sem nenhuma orientação formal acerca de sua estrutura e de seu funcionamento" (DAMASCENO, 2017, p. 239).

Em seu primeiro capítulo, que se dedicava à instrução primária, a Lei determinava que a instrução primária geral deveria ser gratuita para todos os cidadãos, devendo a mesma ser ensinada em escolas e com duas classes de estudo. A primeira classe compreendia o estudo de Leitura e Escrita ou Caligrafia, Princípios de Aritmética com o perfeito conhecimento das quatro operações aritméticas em números inteiros, fracionados, complexos e proporções; Gramática da Língua Nacional e Elementos de Ortografia. A segunda abrangia os Princípios de Moral Cristã e da Religião do Estado, Noções de Civilidade, Elementos Gerais de Geografia, Leitura da Constituição e da História do Brasil. Para as alunas do sexo feminino, além das matérias para as duas classes, seria também abordado o "uso da agulha de cozer, e de meia; o bordado, as regras de talhar e cozer 


\section{(cc) EY}

os vestidos, e os mais misteres próprios da educação doméstica" (art. $3^{\circ}$ ) (PARÁ, 1841, p. 52) o que nos faz perceber que a instrução da mulher já era voltada para os trabalhos domésticos.

A Lei determinava, em seu artigo $4^{\circ}$, que o método do ensino para a instrução primária seria o do Barão De Gerando ${ }^{2}$, o que, na prática, significava a adoção do método de ensino mútuo. Além disso, também era estabelecido que as escolas deveriam receber do Governo da Província “Compêndios, Livros, Traslados de Caligrafia, Globos e Mapas, à vista de um orçamento anual organizado pelos Professores e aprovado pelo Diretor" (art. 5) (PARÁ, 1841, p. 52).

O Presidente da Província era quem definia o local de funcionamento dessas escolas, "dependendo a sua definitiva fixação da aprovação da Assembléia Legislativa” (art. 6º (PARÁ, 1841, p. 52). Entretanto, se a escola, no decorrer de dois anos consecutivos, deixasse de atender pelo menos dez alunos com frequência efetiva, seria transferida pelo Presidente para um lugar onde pudesse ser frequentada por maior número de alunos.

No segundo capítulo, que trata da instrução secundária, a Lei determinava que esse nível seria desenvolvido em Liceus e compreenderia dois cursos: humanidades e comércio. O de Humanidades, com duração de cinco anos, devendo ser constituído pelas cadeiras de Língua Latina; Língua Francesa; Aritmética, Álgebra e Geometria; Filosofia Racional e Moral; História Universal, Geografia Antiga, Moderna e História do Brasil; Retórica, Crítica, Gramática Universal e Poética; Escrituração Mercantil, Contabilidade.

O curso de Comércio, tinha a duração de dois anos e era composto por Língua Francesa; Aritmética, Álgebra e Geometria; Filosofia Racional e Moral; História Universal, Geografia Antiga, Moderna e História do Brasil; Escrituração Mercantil, Contabilidade e Língua Inglesa.

Na Província era permitido apenas um Liceu, tendo sua sede na capital e denominado de "Lycêo Paraense e permanecerá enquanto for conveniente" (art. 11) (PARÁ, 1841, p. 53). Finalizando o capítulo, a Lei cria uma Cadeira de Latim na Vila de Bragança e conserva as de Cametá, Macapá e Santarém. No seu último artigo (13) um aspecto que merece destaque é a prescrição de que deveria haver na capital uma aula de Ensino Normal.

Neste contexto, a Escola Normal da Província do Pará fora criada por meio da Lei $\mathrm{n}^{\circ} 669$ de 13 de abril de 1871, no final do Governo do Presidente Joaquim Machado Portela, nascendo já com grandes expectativas, que nas palavras do então Presidente da Província, Abel Graça, a instituição resolveria as causas do atraso da instrução na Província "graças a lei n. 669, e aos regulamentos, que sob as suas bases foram magistralmente organizados pelo hábil administrador, o sr. 


\section{$(\infty)$ EY}

dr. Portella, meu illustre amigo e antecessor" (GRAÇA apud MALHEIROS; ROCHA, 2014, p. 221).

No terceiro capítulo, que tratava dos professores, a Lei determinava que devesse haver “tantos professores do Ensino Primário, quanto forem as respectivas Cadeiras, competindo a cada um a consignação anual de quatrocentos mil réis, e o de Ensino Normal, o de seiscentos mil réis" (art. 14) (PARÁ, 1841, p. 53). No Liceu, por outro lado, seriam oito os professores "os quais vencerão o ordenado de seiscentos mil réis cada um" (art. 15) (PARÁ, 1841, p. 53-54), além de três substitutos com o ordenado de quatrocentos mil réis ${ }^{3}$.

Em relação ao emprego de professor, a Lei garantia sua vitaliciedade e que seria provido por pessoas idôneas. O ingresso na carreira far-se-ia por meio de concurso, mas se expirado o prazo marcado não comparecessem candidatos, o Presidente proveria as vagas por meio de pessoas idôneas e de reconhecida capacidade para o Magistério (art. 17) (PARÁ, 1841). Também estava previsto que nenhum professor poderia ser demitido sem preceder sentença e, caso acontecesse, o professor só poderia perder o emprego mediante:

$\S 1^{\circ}$. Condenação à pena de galés, ou por crime de estupro, rapto, adultério, roubo ou furto, ou por algum outro da Classe daqueles que ofendem a moral pública e a Religião do Estado.

$\S 2^{\circ}$. Abandono da Escola por tempo consecutivo excedente a três meses, sem causa justificada.

$\S 3^{\circ}$. Negligência habitual e incorrigível no cumprimento dos seus deveres (Art. 18). (PARÁ, 1841, p. 54).

Por outro lado, o Diretor poderia suspender os professores "correcionalmente por omissões, ou faltas pequenas até um mês; e nos casos de maior gravidade deprecará ao Juiz competente para lhe formar o Processo" (art. 19) (PARÁ, 1841, p. 54). Entretanto, depois de ouvido o professor, o Diretor deveria, antes, comunicá-la ao Presidente da Província, que poderia julgá-la improcedente, caso a entendesse sem fundamento.

O quarto capítulo tratava do diretor, determinava a criação, na capital da Província, do cargo de Diretor da Instrução Pública, “com o ordenado de um conto de réis fornecido pelo Tesouro Provincial de tudo que for preciso para o desempenho de suas atribuições" (art. 22) (PARÁ, 1841, p. 55), relacionando-as a seguir:

$\S 1^{\circ}$. Presidir ao Conselho de Instrução Pública, convocá-lo extraordinariamente, e ter voto de desempate.

$\S 2^{\circ}$. Fazer executar as Leis, as ordens do Governo e as decisões do Conselho. 


\section{$(\mathrm{cc})$ EY}

$\S 3^{\circ}$. Inspecionar e fiscalizar todas as Escolas Públicas e Particulares por si, e por intermédio das Câmaras Municipais respectivas, com quem se comunicará.

$\S 4^{\circ}$. Por concurso as Cadeiras que forem vagando, e levar ao conhecimento do Governo quais os Candidatos mais distintos para, dentre eles, escolher um.

$\S 5^{\circ}$. Escolher de acordo com o Conselho, e Compêndios e Modelos das Aulas, e dar as providências necessárias para que a instrução seja regular e uniforme em toda a Província.

$\S 6^{\circ}$. Dar aos Professores todas as Instruções e esclarecimentos necessários para o desempenho das suas obrigações, e exigir dos mesmos e das Câmaras Municipais as informações que julgar convenientes.

$\S 7^{\circ}$. Dar certificado em cada um dos Cursos aos Alunos que o tiverem concluído, o qual será assinado pelo Diretor e Secretário.

$\S 8^{\circ}$. Formar anualmente um relatório do Estado de Instrução em toda a Província para ser presente a Assembléia por intermédio do Governo. (PARÁ, 1841, p. 5556).

Outro aspecto importante da Lei é a referência feita ao Conselho de Instrução (Capítulo $5^{\circ}$ ), que deveria ser composto pelo Diretor e por todos os Professores do Liceu, competindo a essa instância:

$\S 1^{\circ}$. Fazer uma Sessão ordinária na primeira quinta-feira de cada mês.

$\S 2^{\circ}$. Propor à Assembléia Provincial os melhoramentos de que julgar suscetíveis os Estudos, por intermédio do Governo da Província.

$\S 3^{\circ}$. Formar os Regulamentos das Escolas do Ensino Primário e secundário, alterá-los e modificá-los quando convier.

$\S 4^{\circ}$. Formar o Programa da frequência das Aulas, estabelecendo as horas da entrada.

$\S 5^{\circ}$. Reunir-se no primeiro mês de férias para examinar os alunos, e em qualquer ocasião que for necessário para examinar os Candidatos às Cadeiras, que deverão ter as habilitações requeridas no art. $8^{\circ}$ da Lei Geral, de 15 de outubro de 1827, além dos requisitos especificados na presente Lei.

$\S 6^{\circ}$. Conferir prêmios aos alunos de mais distinto mérito.

$\S 7^{\circ}$. Prover nos casos omissos aquilo que for a bem da Instrução Pública. (Art. 25). (PARÁ, 1841, p. 56).

O último capítulo, das Disposições Gerais, tratava de diversos assuntos entre eles o estabelecimento de período para o exame dos alunos; o prêmio que seria concedido ao aluno considerado mais distinto; a forma dos certificados - que seria determinada pelo Conselho de Instrução Pública; a criação dos cargos de secretário e contínuo, ambos do Liceu - o primeiro com o vencimento de duzentos mil e o segundo com cento e cinquenta mil réis - e os valores para o pagamento de certidões e certificados.

Após a promulgação da Lei 97, nos termos aqui expostos, seria de se esperar que transformações mais profundas quanto à instrução pública fossem implementadas, modificando o quadro geral da educação na província. 


\section{$(c)$ EY}

Porém, mesmo com essa iniciativa os problemas quanto ao ensino público ainda existiam. Segundo Damasceno (2017) o presidente voltaria a destacar que a situação ainda não era satisfatória, ressaltando inclusive que "enquanto permanecessem as causas que obstruíam seu desenvolvimento e progresso" (MORAES, 1847, p. 14 apud DAMASCENO, 2017, p. 254).

Essas dificuldades de desenvolvimento e progresso não são diferentes dos dias atuais mesmo já tendo se passado mais de 150 anos - visto que eram dificuldades quanto à manutenção estrutural das escolas, além da falta de equipamentos e material pedagógico, baixa remuneração de professores e ausência de pessoal qualificado para o magistério eram problemas que já faziam parte do cotidiano educacional já naquele período.

\section{A LEGISLAÇÃO EDUCACIONAL E O ENSINO RELIGIOSO}

A partir do já mencionado Ato Adicional de 1834 as províncias passaram a ter mais autonomia e a produzir sua própria legislação a respeito do ensino. No Pará não foi diferente e entre os anos de 1841 e 1887 é possível identificar um conjunto de normas que consolidou o ensino de religião nesta província, quais sejam: a Lei n ${ }^{\circ} 97$ de junho de 1841, que criou o Liceu Paraense e regulou a instrução primária e secundária da Província; a Lei n 203 de outubro de 1851, que reformou a instrução primária e secundária; o Regulamento de abril de 1860, que reformou a instrução primária da Província; a Lei n 664 de outubro de 1870, que dividiu o ensino primário em inferior e superior e deu providências relativas à reforma da instrução primária; a Portaria de abril de 1871, que deu novo regulamento à instrução pública da Província; a Portaria de janeiro de 1874, que deu novo regulamento à instrução pública da Província; a Portaria de maio de 1887, que, deu instruções provisórias para o ensino público; o Oficio de agosto de 1887, que aprovou o regimento interno das escolas públicas da Província e finalmente a Lei nº 1329 de dezembro de 1887, que equiparou os vencimentos de professores e criou novas disposições para o regimento do ensino dividindo-o em dois graus.

Essa legislação reforça a ideia de Muniz; Gonçalves (2015), de que:

A trajetória do Ensino Religioso até se constituir em disciplina escolar, assim como sua permanência no currículo, coloca em evidência sua construção social e histórica, as relações de poder e interesses que a forjaram, na qual se destaca a natureza reguladora da religião, e, por conseguinte, a atribuição dada a essa disciplina como elemento fundamental na formação moral do cidadão brasileiro, 


\section{$(\mathrm{cc})$ EY}

que encontra legitimidade nos valores propalados pelo cristianismo. (MUNIZ; GOLÇALVES, 2015, p. 12).

As primeiras iniciativas relativas à instrução do povo paraense só puderam ser tomadas com o fim da Cabanagem, já sob o lume da Lei $\mathrm{n}^{\circ}$ 16, de 12 de agosto de 1834, conhecida como Ato Adicional Diogo de Feijó pois, de acordo com Oliveira (2004) este dispositivo "promove uma das primeiras políticas de descentralização administrativa, conferindo às Províncias o direito de legislar sobre a instrução pública e de promover estabelecimentos próprios” (OLIVEIRA, 2004, p. 948).

O Ato de 1834 faz uma única menção à instrução, determinando em seu parágrafo $2^{\circ}$ do artigo 10 competências que as assembleias provinciais passariam a ter, entre elas, a de legislar sobre a instrução pública e estabelecimentos próprios para promovê-la, com exceção das instituições de nível superior e outras congêneres. Veja-se o original:

Art. 10. Compete ás mesmas Assembléias legislar:

$\S 2^{\circ}$. Sobre instrucção publica e estabelecimentos proprios a promove-la, não compreendendo as faculdades de Medicina, os Cursos Juridicos, Academias actualmente existentes e outros quaisquer estabelecimentos de instrucção que para o futuro forem creados por lei original. (BRASIL, 1834)

É a partir desse momento que o país irá experimentar um esforço mais significativo no sentido de atender à premissa de instruir as "classes inferiores" enquanto tarefa fundamental para a criação de uma nacionalidade própria. A partir de 1835, abrangendo todo o Império "as Assembleias Provinciais e os presidentes das províncias fizeram publicar um número significativo de textos legais, levando-nos a acreditar que a normatização legal constituiu-se numa das principais formas de intervenção do Estado no serviço de instrução.” (FARIA FILHO, 2000, p. 137).

Apesar disso, alguns fatores dificultaram a efetivação da instrução pública, como o pouco investimento na área e a carência de pessoas habilitadas para o magistério. Além disso, havia a ideia de que a escola não era um bem necessário, como diz Faria Filho "nem a própria escola tinha um lugar social de destaque, cuja legitimidade fosse incontestável” (2000, p. 135).

Mesmo assim, observam-se uma profusão de normas que tinham o objetivo de organizar um sistema de instrução pública a começar pela já mencionada Lei nº 97 de junho de 1841, que criou o Liceu Paraense e regulou a instrução primária e secundária na província do Pará, determinando que os "Princípios da moral e Christã e da Religião do Estado" deveriam estar presentes entre os conteúdos programáticos. Além disso, a religião também tinha influência na 


\section{$(\mathrm{cc}) \mathbf{E Y}$}

demissão de professores pois "daqueles que ofendem a moral publica e a Religião do Estado" (PARÁ, 1841) poderiam ser demitidos sem necessidade de sentença.

Posteriormente, tivemos a Lei $\mathrm{n}^{\circ} 203$ de Outubro de 1851, que reformou a instrução primária e secundária estabelecendo que, tanto no primeiro quanto no segundo grau, para meninos e meninas se ensinariam "noções dos deveres Moraes e religiosos" (PARÁ, 1851), fator que também influenciava nos requisitos para admissão e demissão dos professores, pois estes deveriam ter bom comportamento moral e religioso, podendo ser demitidos também, caso ofendessem a moral pública ou a religião do Estado.

Em abril de 1860 tivemos o Regulamento que reformou a instrução primária da província e que também regulamentava, nos artigos 15, 16 e 17, o ensino de "noções dos deveres moraes e religiosos". Este regulamento estabelecia a conduta desejada para os professores que deveriam justificar, como previsto no artigo 12, "sua conducta, moral, civil e religiosa". No caso das escolas particulares de instrução primária, era necessário que "a pessoa que a requerer professar a religião do Estado" (Art. 96). Esta norma também determinava a demissão dos professores caso estes ofendessem a moral pública ou a religião do Estado.

Dez anos depois, em outubro de 1870, foi editada a Lei $\mathrm{n}^{\circ} 664$ que dividia o ensino primário em inferior e superior, e dava providências relativas à reforma da instrução primária, estabelecendo que no ensino primário inferior deveriam ser ensinadas moral civil e religiosa, valendo isto, também, para o ensino feminino.

Logo após, foi baixada a Portaria de abril de 1871, que dava novo regulamento à instrução pública da Província, recomendando que o ensino primário nas escolas públicas deveria conter aulas de "Instrucção moral e religiosa." e a "leitura dos Evangelhos e noticia da Historia Sagrada." (Art. 30) nos seus primeiro e segundo graus, respectivamente. Importante destacar que os materiais utilizados nessas aulas deveriam passar pela aprovação de Prelado Diocesano. A Portaria também determinava que as escolas particulares poderiam ser estabelecidas por "qualquer pessoa nacional ou estrangeira" (Art. 28) sendo estas obrigadas a não ensinar qualquer doutrina que fosse contrária à religião católica e à forma de governo da época, onde isso acontecesse seria permitido ao diretor geral mandar fechar o estabelecimento. Quanto ao curso da escola normal, também deveria seguir os padrões religiosos do período, visto que só eram admitidos alunos que soubessem o catecismo da doutrina cristã (Art. 120). Para assegurar isso também era ensinado aos futuros professores "Instrrucção moral e religiosa" (Art. 108). 


\section{$(c)$ EY}

Em janeiro de 1874 foi baixada outra Portaria, agora instituindo um novo Regulamento à Instrução Pública da Província, onde era estabelecido, no Artigo 19, o ensino de "Instrucção Religiosa" para as escolas elementares de segundo grau e "Leitura da história sagrada" para as escolas efetivas. Como de praxe, os professores somente estariam aptos para o magistério se professassem a religião do Estado e aqueles que não tivessem cometido ofensas à moral e a religião católica, fato que também contribuía para que professores vitalícios perdessem suas cadeiras.

Mais adiante, tivemos a Portaria de Maio de 1887, que dava instruções provisórias para o ensino público, recomendando em seu Artigo $2^{\circ}$, o ensino de "catecismo, noções de Moraes e deveres cívicos." para as escolas de primeiro grau. Nas escolas de segundo grau, de acordo com o artigo $3^{\circ}$, haveria o ensino de "Instrucção religiosa e cívica" e nas escolas provisórias deveria ser ensinada a "doutrina christã".

Também em 1887, no mês de Agosto foi emitido um Ofício que aprovava o regimento interno das escolas públicas da Província estabelecendo em seu Artigo $1^{\circ}$ que nas escolas provisórias, na $1^{\circ}, 2^{\circ}$ e $3^{\circ}$ classe, deveria haver o ensino de "Doutrina crhistã" a se desenvolver da seguinte forma:

Na primeira classe, o ensino religioso limitar-se-há ao signal da Cruz ao Padre Nosso e á Ave-Maria; na segunda, comprehenderá mais a Salve Rainha e o Symbolc dos Apostolos; na terceira, entrarão os Mandamentos da Lei de Deus, os da Santa Madre Igreja, as Obras de Misericordia e os Sete Sacramentos. (PARÁ, 1887).

Ainda segundo este ofício nas escolas de primeiro grau os alunos também deveriam ser divididos em classes, havendo em todas o ensino de "Religião". Para as escolas de segundo grau, também divididas em classes, era ensinada a "Instrucção Religiosa" apenas na primeira classe. No seu artigo $9^{\circ}$, ficava estabelecido que "Os alumnos acatholicos não serão obrigados a acompanhar os exercicios religiosos".

Finalmente, em dezembro de 1887 foi promulgada a Lei ${ }^{\circ} 1329$ de Dezembro de 1887 , que equiparava os vencimentos de professores e criava novas disposições para o regimento do ensino dividido em dois graus; estabelecendo que os professores de primeiro grau eram obrigados a ensinar religião. Neste ofício também existe uma menção a alunos que não professassem a religião do Estado, tratando os mesmos como "acatholicos" estabelecendo que estes alunos não seriam obrigados a participar dos exercícios religiosos. Porém, anterior e posteriormente a esse ofício nada é mencionado sobre essa "classe" de alunos. 


\section{$(c)$ EY}

Como se pode perceber, um dos aspectos a destacar no conjunto dessa legislação é a obrigatoriedade de cursar as disciplinas que vinculadas ao ensino da religião católica. Mesmo com mudanças em sua nomenclatura a disciplina se fez presente nos nove documentos, o que corrobora a inegável interferência da Igreja na formação dos súditos do Império, impondo o aprendizado dos princípios do catolicismo.

Como forma de garantir a instrução religiosa, a religião do Estado também era requisito para a admissão e demissão dos professores, sendo estabelecida à eles a obrigatoriedade de professar o catolicismo e a punição para aqueles "ofendessem" a religião do Estado, ficando estes, sujeitos à demissão. Na portaria de abril de 1871, por exemplo, ficava estabelecido que o magistério só poderia ser exercido por católicos, o que deveria ser comprovado através de atestado dos párocos.

\section{CONSIDERAÇÕES FINAIS}

Neste trabalho observamos a implantação tardia de um ensino sistematizado no Brasil, que se caracterizava por ser resultante de um aparato jesuítico. Importante destacar a notoriedade da ideia de que o ensino religioso na educação pública brasileira apareceu no contexto da colonização do país enquanto ensino da doutrina cristã católica, catequese e ensino da religião (MUNIZ; GOLÇALVES, 2015). Posteriormente, o sistema jesuítico foi substituído pelo sistema do diretório pombalino que deu início a uma nova etapa da educação brasileira. Entretanto o sistema escolar do período imperial acabou se constituindo em uma cópia do modelo jesuítico no que se refere a "noção de classe e de sala de aula, com o papel dos exercícios e das antologias, com o domínio do corpo e a disciplina do silêncio - o exercício da repetição e as virtudes pedagógicas da memória" (SOUZA, 1998, p. 83).

Também percebemos o ensino de religião como disciplina obrigatória para as escolas da época a partir do reconhecimento de sua importância para a Coroa e identificamos como era organizado ensino de religião no Império a partir da legislação educacional do período, levando em consideração a Constituição do Império e o Ato Adicional Diogo de Feijó.

Assegurada sua inserção no currículo o ensino religioso ganhou força e poder e atraiu outros públicos poderosos que corroboraram para sua permanência. Por outro lado, é forçoso reconhecê-lo como "um corpo de conhecimento elaborado em meio a conjunturas internas e 


\section{$(\mathrm{cc}) \mathbf{E Y}$}

externas, envolto por um aparato profissional, com finalidade educativa, certa estabilidade curricular e dotada de organização própria para o ensino" (MUNIZ; GOLÇALVES, 2015, p. 05), inserido e executado no âmbito da instrução pública daquele período.

Além disso, o formato do catecismo, com perguntas e respostas padronizadas acabou se tonando espelho para as avaliações escolares, servindo para a avaliação de alunos e professores (SOUZA, 1998), desta forma é possível perceber que "a noção de catecismo mostra a subordinação da escola à Igreja, num texto que elogia incidentemente as virtudes da memória" (SOUZA, 1998, p. 84).

Com a Constituição de 1891, o Brasil passou a ser um Estado laico, tendo o dever de garantir a todos a liberdade de professarem sua fé, sem interferência do Estado. Mas, mesmo antes da promulgação da primeira Carta Magna republicana o ensino religioso foi banido das escolas públicas pelo Ministro na Instrução Pública, Correios e Telégrafos, Benjamim Constant, entrando em curso "uma disputa pelo campo do lugar da religião na educação. Forma-se o embate entre o público e o privado, entre o religioso e o laico" (CASTRO; BALDINO, 2015, p. 72).

Constatamos que o ensino religioso foi e continua sendo objeto de mudanças e reflexões permanentes, desde a sua criação e implementação pela Igreja Católica no período colonial e sua trajetória, até se constituir em disciplina escolar, levando em consideração as relações entre Igreja e Estado desde aquele momento, quando o campo religioso e estatal se fundem, foi permeada por disputas de espaço no âmbito da escola pública.

\section{REFERÊNCIAS}

BASTOS, Maria Helena Câmara. A formação de professores para o ensino mútuo no Brasil: "o Curso normal para professores de primeiras letras do Barão de Gérando (1839)". História da educação, v. 2, n. 3, p. 95-119, 1998.

BRASIL. Ato Adicional de 1834. Município Neutro, 1834.

BRASIL. Constituição de 1824. Município Neutro, 1824.

CASTRO, Raimundo Márcio Mota de; BALDINO, José Maria. O Ensino Religioso no Brasil: a constituição de campo disputado. Revista de Estudos da Religião, v. 15, n. 2, p. 67-79, 2015.

DAMASCENO, Alberto. Duas escolas, dois destinos: O império e a instrução na província do Grão-Pará em meados do século XIX. In: IX CONGRESSO BRASILEIRO DE HISTÓRIA DA 
EDUCAÇÃO JOÃO PESSOA, 9., 2017, Universidade Federal da Paraíba. Anais Eletrônicos. Paraíba, 2017.

FARIA FILHO, Luciano Mendes. Instrução elementar no século XIX. In: LOPES, E. M. S. T.; FARIA FILHO, L. M.; VEIGA, C. G. (Org.). 500 anos de educação no Brasil. 2. ed. Belo Horizonte, MG: Autêntica, 2000.

COSTA, Benedito Gonçalves; FRANÇA Maria do Perpétuo Socorro G. S. A. C. A igreja como educadora: o asilo de Santo Antônio formando a mulher cristã de trabalho e piedade (1878 1888). Revista HISTEDBR On-line, Campinas, n. 62, p. 53-68, maio 2015.

KRIPKA, Rosana Maria L.; SCHELLER, Morgana; BONOTTO, D. de L. Pesquisa documental na pesquisa qualitativa: conceitos e caracterização. Revista de investigaciones UNAD, v. 14, n. 2, p. 55-73, 2015.

MALHEIROS, Rogério Quimarães; ROCHA, Genylton Odilton Rêgo da. Escola Normal do Pará: aspectos históricos, econômicos e sociais acerca da constituição dos ideais de instrução e formação de professores entre a classe dirigente da Província do Grão-Pará (1850-1871). Revista Margens Interdisciplinar, [S.1.], v. 8, n. 10, p. 227-246, maio 2016. Disponível em: 〈https://periodicos.ufpa.br/index.php/revistamargens/article/view/2736/2861>. Acesso em: 11 ago. 2020.

MORTATTI, Maria do Rosário Longo. Notas sobre linguagem, texto e pesquisa histórica em educação. História da educação, v. 3, n. 6, p. 69-77, 1999.

MOEDAS DO BRASIL. Reformas Monetárias. [S.1.], 2015. Disponível em: http://www.moedasdobrasil.com.br/reformas.asp. Acesso em: 11 jul. 2019.

MUNIZ, Tamires Alves; GONÇALVES, Ana Maria. Ensino religioso: história de sua constituição como disciplina escolar. In: 37 REUNIÃO NACIONAL DA ANPED, 37., 04 a 08 out. 2015, UFSC. Anais [...]. Florianópolis: 2015.

OLIVEIRA, Marcos Marques de. As origens da educação no Brasil: da hegemonia católica às primeiras tentativas de organização do ensino. Ensaio: aval. pol. públ. Educ., Rio de Janeiro, v. 12, n. 45, p. 945-958, 2004.

PARÁ (Estado). Lei no 1329 de dezembro de 1887. Equipara os vencimentos de professores e cria novas disposições para o regimento do ensino, dividindo-o em dois graus. Belém, 1887.

PARÁ (Estado). Lei no 203, de outubro de 1851. Reforma a instrução primária e secundária da Província. Belém, 1851.

PARÁ (Estado). Lei $\mathbf{n}^{\circ} 664$ de outubro de 1870. Divide o ensino primário em inferior e superior e dá providências relativas à reforma da instrução primária. Belém, 1870. 
PARÁ (Estado). Lei n ${ }^{\circ}$ 97, de junho de 1841. Cria o Liceu Paraense e regula a instrução primária e secundária da província do Pará. Belém, 1841.

PARÁ (Estado). Ofício de agosto de 1887. Aprova o regimento interno das escolas públicas da província. Belém, 1887.

PARÁ (Estado). Portaria de abril de 1871. Dá novo regulamento à instrução pública da província. Belém, 1871.

PARÁ (Estado). Portaria de janeiro de 1874. Deu novo regulamento à instrução pública da província. Belém, 1874.

PARÁ (Estado). Portaria de maio de 1887. Dá instruções provisórias para o ensino público. Belém, 1887.

PARÁ (Estado). Regulamento de abril de 1860. Reforma a instrução primária da Província. Belém, 1860.

SOUZA, Maria Cecília Cortez Christiano de. Decorar, lembrar e repetir: o significado de práticas escolares na escola brasileira do final do século XIX. In: SOUSA, Cynthia Pereira de. História da educação: processos, práticas e saberes. São Paulo: Escrituras, 1998.

NOTAS

1. Sebastião José de Carvalho e Melo nasceu em 1699 [...] As ambições políticas que alimentava só começaram a apresentar alguma perspectiva quando, já com quase 40 anos, se deslocou para a corte da Inglaterra como diplomata. [...] Marquês de Pombal buscava conquistar em sua pátria algum cargo importante no qual pudesse pôr em prática novos modelos econômicos e políticos. [...]. Em junho de 1759 recebe o título de Conde de Oeiras e em 1769 torna-se o Marquês de Pombal, denominação que o consagrou tanto na política como na historiografia (SAVIANI apud CASTRO; BALDINO, 2015 p. 69).

2. De Gérando foi secretário-geral e presidente da Société pour l'instruction élémentaire, que dominou a vida pedagógica francesa, durante 20 anos, e assegurou a promoção do método mútuo, acompanhado de grande progresso da instrução popular (BASTOS, 1998).

3. Já popularmente adotada como unidade monetária brasileira, o mil-réis foi oficializado em 08.10.1833 através da Lei 59, assinada no $2^{\circ}$ Império, pela Regência Trina durante a menoridade de D. Pedro II. Essa Lei reorganizou, sob vários aspectos, o Sistema Monetário Brasileiro. Mil-réis passou a designar a unidade monetária e réis os valores divisionários. Na mesma época ficou conhecido o conto de réis, tratando-se do montante equivalente a 1 milhão de réis, ou mil mil-réis. Rs 1:000\$000 $=1$ conto de réis $=1000$ mil-réis $=1$ milhão de réis (MOEDAS DO BRASIL, 2015). Gomes (2008), apresenta uma conversão dos réis do Império para o Real de nossos dias baseado em outros autores. Lembrando que a conversão, mesmo aproximada, não é exata, A conversão proposta é a seguinte: 1 Real $($ Réis) $=\mathrm{R} \$ 0,123$ e 1 Mirréis (Mil Réis) $=\mathrm{R} \$ 123,00$. Seguindo este raciocínio quatrocentos mil réis equivaleriam, nos dias de hoje, a $\mathrm{R} \$ 49.200,00$ (quarenta e nove mil e duzentos reais).

Recebido em: 16 de dezembro de 2019 Aceito em: 06 de maio de 2020 